\title{
Analysis of the Return and Risk of Investment in Insurance Companies Listed on the Indonesia Stock Exchange
}

\author{
Aizzah Sifaur Robbyah ${ }^{1}$, Ferry Khusnul Mubarok ${ }^{2}$, \\ Rahman E1 Junusi ${ }^{3}$, Rofiul Wahyudi ${ }^{4}$ \\ ${ }^{1,2,3}$ Fakultas Ekonomi dan Bisnis Islam, Universitas Islam Negeri Walisongo Semarang \\ ${ }^{4}$ Faculty of Islamic Religion, Universitas Ahmad Dahlan \\ *Correspondence email: azizah_sifaur_robbyah@gmail.com
}

\section{背勒}

ISSN: 1979-4703 (p)

ISSN: 2527-9726 (e)

\section{Article history: \\ Received 2 Pebruary2021 \\ Accepted 30 May 2021 \\ Published 30 June 2021}

Keywords:

Investment, Risk, Return, Macroeconomy

\section{Introduction}

Currently, investment is one of the choices for most people to allocate some of their assets. Investments are made to get profits or benefits in the future at the expense of some current assets (Mubarok,

\section{A B S T RACT}

The return and risk of stock investment have a high level of volatility because it depends on fundamental and technical conditions and the influence of micro and macro variables. This study aims to determine the risk and return on investment in insurance companies and analyze the effect of macroeconomic variables on the level of risk and return on investment in insurance companies. The sampling technique used was purposive sampling. Data analysis shows that for three years, Asuransi Jasa Tania Tbk has the highest level of conclusion, which is $22.3 \%$, and Asuransi Harta Aman Pratama Tbk. has the lowest rate of $-3.3 \%$. For three years, the value of Gross Domestic Product has increased successively so that this will cause a stock return that is proportional to the level of risk that will be faced. Changes in the inflation rate up and down for three consecutive years have a different effect every year where when the inflation rate decreases, the rate of return on investment will be high. In addition, the interest rate decreased from $4.75 \%$ in 2016 to $4.25 \%$ in 2017. Then it increased to $6.00 \%$ in 2018 . The Rupiah exchange rate against the dollar is getting weaker, indicating an increase in the exchange rate. Every year from 2016 to 2018. When the rupiah exchange rate weakens, people will choose to invest in foreign currencies because the value of these foreign currencies can determine the size of the risk of a business.
2018; Nababan et al., 2019). Investment is a delay in current consumption to be included in productive assets for a certain period (Amelisah \& Sholichah, 2021). Thus investment can be understood as a present sacrifice to get more benefits in the future. Investments are classified into 
two types, namely real assets and financial assets (Permana, 2017). Real asset investment is an investment of intangible assets such as buildings, land, property, apartments, houses, land, etc.

In contrast, investment in financial assets or financial assets is an investment in intangible assets but has value and is valuable due to contract claims, such as bank deposits, stocks, and bonds (Egam et al., 2017). Investments in real assets and financial assets each have advantages and disadvantages, so investors must choose and consider various things before investing. Things that must be considered are related to risk and return (Zulkarnaen, 2018). Risk and return are two things that cannot be separated in making investment decisions because investment considerations are sacrifices to gain profits or trade-offs from risk and return (Mubarok et al., 2017). That way, risk and return have a positive relationship. The greater the risk that must be borne, the greater the return received.

Return on what has been invested is the most important aspect that must be considered in investment decisions (Oussama \& Lamine, 2021). Return or return is the level of profit investors enjoy on a stock investment made (Damayanti \& Kuswanto, 2019). In simple terms, returns can be interpreted as the results obtained from investments. Naturally, investors want a high rate of return because the purpose of investors investing is to get money from the profits from investing (Nur et al., 2018; Tian et al., 2021). However, in addition to considering a high rate of return, investors should also consider the risks accepted by investing (Aryaningsih et al.,
2018). Risk is the possible difference between the actual return received and the expected return (Harnida, 2017). Everything has risks, including investing. For this reason, a company is required to have decisions in investing. These decisions will affect the company's value through risk and return factors because the level of profit obtained by shareholders is different and uncertain, so these factors must be considered.

In addition to calculating risk, investment is also often associated with investment returns (return). This is because the investor's goal is to obtain the maximum possible return, so investors need to consider the factors that affect the return obtained, both macroeconomic and microeconomic factors (Permana, 2017; Rivero et al., 2021). Macro factors come from outside the company, for example, the economy, domestic political events, international political events, law, technology, and others. In contrast, micro factors come from within the company, such as earnings per share, debt-equity ratio, and other financial ratios (Zharikova \& Cherkesenko, 2021). Many types of research on the return and risk of investing in stocks have been carried out. However, there are still differences in results. Damayanti \& Kuswanto's research (2019) concludes that a stock has a fairly high return and risk volatility, in a certain period, the stock will have a high risk and high profit, and vice versa, which causes the return and risk of a stock to be positive or negative. Return volatility and risk also occur in companies, both fundamentally and technically, both the influence of micro and macroeconomic variables (Awwaliyah et al., 2019; Berry \& 
Jianren, 2021; Dharma, 2019; Reyna et al., 2021; Sastrodiharjo \& Sutama, 2015; Sena \& Suherman, 2021; Suyatna, 2021; Wang \& Zhu, 2021). The purpose of this study is to analyze the level of return and investment risk in insurance companies listed on the Indonesia Stock Exchange, which are associated with macroeconomic factors.

\section{Literature Review}

\section{Investment in Capital Market}

The capital market is a market for various long-term financial instruments that can be traded, both equities (stocks), mutual funds, debt securities (bonds), derivative instruments, and other instruments (Mubarok, 2019). The capital market is a means for companies to increase their long-term funding needs by selling shares or issuing bonds. According to the Capital Market Law No. 8 of 1995 concerning the Capital Market, the capital market is defined as activities related to public offerings and securities trading, public companies related to the securities they issue, and institutions and professions related to securities. Thus, it can be concluded that the capital market is a market for trading securities for longterm investments by bringing together those who need funding and those who have more funds. Investment is investing or placing assets in the form of assets or funds in something expected to generate income or increase in value in the future (Hayati, 2016). Investment is a delay in current consumption to be included in productive assets for a certain period. Thus, investment can be interpreted as sacrificing current assets to get benefits or valuable results in the future (Zhang, 2021).
Financial instruments or products traded in the Indonesian capital market include Stocks, Bonds, Mutual Funds, Exchange Traded Funds, and Derivatives instruments (Al-mutairi et al., 2021; Babayeva, 2021). Shares are a sign of a person or party (business entity) in a company or limited liability company. Bonds are transferable medium-long term debt securities, which contain a promise from the issuing party to pay interest in the form of interest in a certain period and pay off the principal at a predetermined time to the bond buyer. Mutual funds are a forum used to collect public funds for further investment in securities portfolios by investment managers. ExchangeTraded Fund (ETF) is a mutual fund in a collective investment contract whose participation units are traded on the stock exchange. ETF combines mutual funds for its management, while the mechanism is buying and selling shares. Derivatives are financial contracts between two or more parties to fulfill promises to buy or sell assets or commodities traded as objects at a time and price mutually agreed between the seller and the buyer.

A company, when it needs funds, can sell its ownership rights in the form of shares. Stocks are one of the most popular instruments for investors. Shares are a sign of a person or party (business entity) in a company or limited liability company (Hutapea et al., 2017). According to Tandelilin, shares are proof of ownership of the company's assets that issued the securities. Shares are divided into two different types, namely common stock and preferred stock. The difference between these two stocks is that preferred stock has a higher position than common stockholders, namely having a claim on 
the company's assets and distributing dividends first. Preferred stock is more difficult to trade than common stock because the number of preferred stock is small. The advantage of investing in stocks is getting in the form of dividends and capital gains. Dividends are profitsharing by the company that comes from the profits generated by the company. Meanwhile, Capital gain is the difference between the purchase price and the selling price formed due to stock trading activities in the secondary market.

\section{Investment Risk}

Investment risk is the possibility of results that deviate from expectations. In portfolio theory, the risk is the deviation of expected returns (Bacinello et al., 2020; Rustamunadi \& Amaliah, 2020). According to Tandelilin, the risk is the possible difference between the actual and expected returns (Damayanti \& Kuswanto, 2019; Oudat \& Ali, 2021). Stock investment risk is divided into systematic risk and unsystematic risk. Systematic risk arises due to macroeconomic factors that affect all securities, which cannot be eliminated by diversification (Markonah, 2021; Upreti et al., 2021).

Meanwhile, unsystematic risk is the risk that arises due to unique factors in security and can be eliminated by diversification (Möhlmann, 2021). Unique factors include capital structure, asset structure, company size, level of liquidity, and conditions and environment (Bacinello et al., 2020; Thuku, 2021). Meanwhile, according to macro factors, among others, the condition of the economy, namely the current condition of economic activity or not. A situation in which the economy is experiencing development, recession, or stability can be called an economic condition (Arintoko et al., 2021). For example, in a recession, people's purchasing power decreases so that companies have difficulty marketing their products. This will cause investors to be reluctant to buy shares so that the stock price will decrease and the risk will be high. Second, inflation is a measure of the increase in product prices. Investors cannot afford to buy stocks when inflation is high, so that stock prices will decrease and risk will increase. Third, the interest rate is when the deposit rate decreases, investors will choose to invest in the capital market. Fourth, the foreign exchange rate compares the value of one country's currency with another. When the foreign exchange rate declines, investors will invest in foreign currency, resulting in a decrease in stock prices and a high stock investment risk.

\section{Return on Investment}

Return or return on investment is the main goal of investors in investing. Return is the reward obtained from investing. Returns are divided into two types: realized returns and expected returns (Ariani \& Zulhawati, 2021; Geriadi \& Wiksuana, 2017). The realized return has occurred and is calculated using historical data (Worotikan et al., 2021). The measurement of realized returns that are widely used is total returns, relative returns, cumulative returns, and adjusted returns (Marsanto et al., 2021).

Meanwhile, the expected return is a return that is expected to be obtained by investors in the future. Several measuring the expected return methods are based on 
the expected future value, the historical return value, and the existing expected return model. Investment return consists of two components, namely capital gain (loss) and yield (Leviany \& Sukiati, 2014). Capital gain (loss) increases or decreases the price of securities that provide profits or losses to investors (Dhiab, 2021). While yield is a return that describes the cash flow or income obtained periodically from investment (Zulkarnaen, 2018).

\section{Research Method}

The population in this study shares in insurance companies listed on the Indonesia Stock Exchange from 2016 to 2018. Sampling uses a purposive sampling method, taking samples determined according to research needs, namely insurance sub-sector companies listed on the Indonesia Stock Exchange that report their company's financial statements. From 2016 to 2018. The sample is ten insurance companies as follows:

Table 1.

Companies and Types of Research Sample Companies

\begin{tabular}{cllc}
\hline No. & \multicolumn{1}{c}{ Company } & \multicolumn{1}{c}{ Type } & Code \\
\hline 1 & Asuransi Harta Aman Pratama Tbk & Finance, Insurance & AHAP \\
2 & Lippo General Insurance Tbk & Finance, Insurance & LPGI \\
3 & Asuransi Ramayana Tbk & Finance, Insurance & ASRM \\
4 & Asuransi Bina Dana Arta Tbk & Finance, Insurance & ABDA \\
5 & Asuransi Dayin Mitra Tbk & Finance, Insurance & ASDM \\
6 & Maskapai Reasuransi Indonesia Tbk & Finance, Insurance & MREI \\
7 & Asuransi Jasa Tania Tbk & Finance, Insurance & ASJT \\
8 & Asuransi Multi Artha Guna Tbk & Finance, Insurance & AMAG \\
9 & Asuransi Kresna Mitra Tbk & Finance, Insurance & ASMI \\
10 & Victoria Insurance Tbk & Finance, Insurance & VINS \\
\hline
\end{tabular}

Source: Economic and Business Data Center

In this study, the type of data used is secondary data with collection methods in the form of library research, research results, websites, and other relevant sources related to the needs of the data to be studied. 1) List of names of financial sector companies in the insurance subsector listed on the Indonesia Stock Exchange for the period 2016 to 2018, presented on the Economic and Business Data Center website, Faculty of Economics, University of Indonesia. 2) Insurance sub-sector company reports are presented in full to the public on the Indonesia Stock Exchange (IDX) website. The company report contains all company data, such as stock closing prices, cash dividends, ROA, ROE, and other relevant data.3) Data on inflation and economic growth in Indonesia for the period 2016 to 2018 are presented on the website of the Central Statistics Agency. 4) Data on interest rates and the Rupiah exchange rate against the Dollar for the period 2016 to 2018 are presented on the Bank Indonesia website.

Stock investment is an activity to invest in shares. The level of risk is the possible deviation between the profit earned and the expected profit and is measured using the standard deviation. The rate of return is the Return on Investment activities 


\section{At-Taqaddum}

Vol. 13 No. 1 (2021) Pg. 73-84

obtained by investors and is measured by return expectations. Investments are valued based on the rate of return and standard deviation (calculation of risk). The formula obtains the rate of return:

Description:

$$
R i=\frac{P i-p o}{p o}
$$

Ri: Rate of return to i

Pi: Stock price in the current period

Po: Stock price in the previous period

The formula obtains the expected rate of return:

$$
E(R)=\sum_{n=1}^{n}\left(\frac{R i}{n}\right)
$$

Description:

Ri: Rate of Return

E(R): Expected Return

$\mathrm{N}$ : Number of data

Risk can be obtained through the standard deviation with the formula:

$$
\sigma=\sqrt{\sum_{n=1}^{n} \frac{(\mathrm{Ri}-\mathrm{R})^{2}}{\mathrm{n}-1}}
$$

Description:

$\sigma$ : Risk of stock investment

$\mathrm{Ri}$ : Stock return in period $\mathrm{i}$

$\mathrm{R}$ : Average stock return

$\mathrm{N}$ : Number of data

Meanwhile, national economic growth is measured by the growth of Gross Domestic Product (GDP). Inflation is the rate of inflation as measured by the growth of the consumer price index. The interest rate is the interest rate for Bank Indonesia certificates. The Foreign Exchange Rate is the Rupiah exchange rate against the US Dollar, which is calculated at the average exchange rate.

\section{Result and Discussion}

Based on the calculations that have been made, the level of risk and return on insurance companies listed on the Indonesia Stock Exchange for a period of 3 years, 2016 to 2018, resulted in the conclusion that in 2016, the Ramayana Insurance company Tbk had the highest rate of return of $5.4 \%$ with a risk level of $5.4 \%$. By $30.3 \%$, and the company Victoria Insurance Tbk has the lowest rate of return of $-1.5 \%$, with a risk level of $8.8 \%$. In 2017, the Asuransi Jasa Tania Tbk had the highest rate of return of $22.3 \%$, with a risk level of $53.8 \%$, and the Insurance company Ramayana Tbk had the lowest rate of return of $-1.3 \%$ with a risk level of $3.4 \%$. In the last year of the study, 2018, the Indonesian Reinsurance Company Tbk had the highest rate of return of $2.5 \%$ with a risk level of $9.7 \%$, and the Pratama Harta Aman Insurance company had the lowest rate of return of $-3.3 \%$ with a risk rate of $3.3 \%$. Risk of $22.2 \%$. For three consecutive years from 2016 to 2018, Asuransi Jasa Tania Tbk has the highest rate of return of $22.3 \%$, with a risk level of $53.8 \%$, and Asuransi Harta Aman Pratama Tbk has the lowest rate of return of $-3.3 \%$ with a risk level of $22.2 \%$. The following is a table related to each company's level of risk and return for three years. 
Table 2.

Level of Risk and Return in 2016 - 2018

\begin{tabular}{lcccccc}
\hline \multicolumn{1}{c}{ Corporate/Company } & \multicolumn{2}{c}{$\mathbf{2 0 1 6}$} & \multicolumn{2}{c}{$\mathbf{2 0 1 7}$} & $\mathbf{2 0 1 8}$ \\
& $\begin{array}{c}\text { Return } \\
\text { expectations } \\
\mathbf{( \% )}\end{array}$ & $\begin{array}{c}\text { Risk } \\
\mathbf{( \% )}\end{array}$ & $\begin{array}{c}\text { Return } \\
\text { expectations } \\
\mathbf{( \% )}\end{array}$ & $\begin{array}{c}\text { Risk } \\
\mathbf{( \% )}\end{array}$ & $\begin{array}{c}\text { Return } \\
\text { expectations } \\
\mathbf{( \% )}\end{array}$ & $\begin{array}{c}\text { Risk } \\
\mathbf{( \% )}\end{array}$ \\
\hline Asuransi Harta Aman Pratama Tbk & $-0,6$ & 8,8 & 0,9 & 13,0 & $-3,3$ & 22,2 \\
Lippo General Insurance Tbk & 1,2 & 13,8 & $-0,8$ & 2,7 & $-0,6$ & 9,2 \\
Asuransi Ramayana Tbk & 5,4 & 30,3 & $-1,3$ & 3,4 & 0,3 & 2,4 \\
Asuransi Bina Dana Arta Tbk & -1 & 6,8 & 0,6 & 6,5 & $-0,3$ & 2,4 \\
Asuransi Dayin Mitra Tbk & -1 & 7,0 & 0,5 & 7,1 & 1,3 & 5,2 \\
Maskapai Reasuransi Indonesia Tbk & $-1,2$ & 16,9 & 0,4 & 14,3 & 2,5 & 9,7 \\
Asuransi Jasa Tania Tbk & 2,4 & 15,0 & 22,3 & 53,8 & $-2,8$ & 16,6 \\
Asuransi Multi Artha Guna Tbk & 0,2 & 8,7 & 0,5 & 9,1 & $-1,1$ & 5,5 \\
Asuransi Kresna Mitra Tbk & $-0,3$ & 25,0 & 5,4 & 9,3 & $-1,9$ & 4,7 \\
Victoria Insurance Tbk & $-1,5$ & 8,8 & 14,6 & 52,9 & $-2,3$ & 15,9 \\
\hline
\end{tabular}

Analysis of Macroeconomic Variables on the Level of Risk and Return on Investment

This study uses four types of macroeconomic variables mentioned in the literature review: economic conditions as measured by the growth of Gross Domestic Product (GDP), inflation, interest rates, and foreign exchange rates. The GDP value had increased from $12,406.8$ trillion in 2016 to $13,588.8$ trillion in 2017 , then increased in 2018 to $14,837.4$ trillion. Thus, it can be concluded that the value of GDP tends to increase for three consecutive years. This is related to the rate of return on the stock that is proportional to the level of risk. From 2016 to 2018, the inflation rate changed from an increase in 2017 from $3.02 \%$ in 2016 to $3.61 \%$ in 2017.
With rising inflation, the stock returns in 2016 tended to decrease. In 2018, the inflation rate decreased from 3.61\% 2017 to $3.13 \% 2018$. With a decrease in inflation, the stock returns in 2017 tended to increase.

In the period 2016 to 2018, interest rates and the Rupiah exchange rate against the Dollar also experienced changes. The interest rate decreased from $4.75 \%$ in 2016 to $4.25 \%$ in 2017 . Then it increased to $6.00 \%$ in 2018. Meanwhile, the Rupiah exchange rate against the Dollar is shown in the table getting weaker, indicated by an increasing number of exchange rates every year from 2016 to 2018. Changes in macroeconomic variables for three years from 2016 to 2018 can be seen in the following table: 
Vol. 13 No. 1 (2021) Pg. 73-84

Table 3.

Changes in Macroeconomic Variables During 2016 - 2018

\begin{tabular}{lrrr}
\hline Macroeconomic Variables & \multicolumn{2}{c}{$\mathbf{2 0 1 6}$} & \multicolumn{2}{c}{$\mathbf{2 0 1 7}$} & \multicolumn{1}{c}{$\mathbf{2 0 1 8}$} \\
\hline GDP (Rp) & $12.406,8$ Trillion & $13.588,8$ Trillion & $14.837,4$ Trillion \\
Inflation $(\%)$ & 3.02 & 3.61 & 3,13 \\
Interest Rate (\%) & 4.75 & 4.25 & 6.00 \\
Exchange rate (Rp) & $13.503,00$ & $13.568,00$ & $13.746,00$ \\
\hline
\end{tabular}

Source: data processed from Bank Indonesia and the Central Statistics Agency

The increase in Gross Domestic Product is a good sign for investment because it causes banking conditions to decline. Investors prefer to invest their funds in the capital market. On the other hand, when the Gross Domestic Product decreases, investors prefer to invest their funds in banking products. Inflation affects stock prices in the long term, ie the effect will occur when inflation has an impact on company sectors related to economic activities in Indonesia. In this case, when inflation increases, it will impact the increase in the price of raw materials for the company, so that production costs will increase and there will be an increase in the price of goods in the market. Thus, inflation causes income to decrease. Investors will usually face rising inflation because investing will reduce the circulation of money and turn it into an investment instrument. High interest rates are bad for investing because they can cause investors to shift their funds from stock investments to savings or time deposits products. In addition to interest rates, the last macroeconomic factor that affects investment is the foreign exchange rate. The strengthening of foreign exchange rates is beneficial when the economy is inflationary. When the rupiah exchange rate weakens, people will choose to invest in foreign currencies because the value of this foreign currency can determine the size of the risk of a business.

\section{Conclusion}

Berdasarkan analisis dan pembahasan, selama 3 tahun yaitu 2016-2018, Asuransi Jasa Tania Tbk memiliki tingkat tertinggi sebesar 22,3\% dengan tingkat risiko sebesar 53,8\%. On the other hand, Asuransi Harta Aman Pratama Tbk has the lowest rate of return of $-3.3 \%$, with a risk level of $22.2 \%$. For three years, the value of GDP has increased from 2016 of 12,406.8 Trillion to $13,588.8$ Trillion in 2017 , then increased in 2018 to $14,837.4$ Trillion, so that this will lead to a stock return that is proportional to the level of risk involved. Will be faced. Changes in the inflation rate affect the rate of return on investment. The higher the inflation rate, the lower the rate of return on investment. In addition, the interest rate decreased from $4.75 \%$ in 2016 to $4.25 \%$ in 2017 . Then it increased to $6.00 \%$ in 2018. Meanwhile, the exchange rate increased every year from 2016 to 2018. When the rupiah exchange rate weakens, people will choose to invest in foreign currencies because the value of this foreign currency can determine the size of the risk of a business. 


\section{Recommendation}

Based on the conclusion of this article, the return and risk of insurance companies have characteristics like other company sectors, plus insurance companies have a positive trend, especially in several companies, so that this is a potential for investors. Therefore, for the next researcher, the recommendation is to expand the research area, especially regarding the year and the variables related to this research.

\section{References}

Al-mutairi, A., Naser, H., \& Naser, K. (2021). Determinants of corporate performance: Empirical evidence from the insurance companies listed on Abu Dhabi securities exchange ( ADX ). Accounting, 7, 143-150. https://doi.org/10.5267/j.ac.2020.1 0.003

Amelisah, \& Sholichah, I. U. (2021). Pengaruh pelayanan, promosi, harga dan citra merek terhadap keputusan pembelian produk dana investasi pada asuransi syariah. Madani Syariah, $4(2), 28-41$.

Ariani, M., \& Zulhawati, Z. (2021). Factors Affecting the Increase of Insurance Income Among Insurance Companies in Indonesia. Advances in Economics, Business and Management Research, 174(Icebm 2020), 449-456.

Arintoko, Aziz, A. A., \& Nur, H. S. (2021). Market Structure and Determinants of Firm Profitability on General Insurance Industry in Indonesia. Studies in Business and Economicss, 16(1), 26-41.

Aryaningsih, Y. N., Fathoni, A., \& Harini, C. (2018). Pengaruh Return on Asset (ROA), Return on Equity (ROE) dan Earning per Share (EPS) terhadap
Return Saham pada Perusahaan Consumer Good (Food and Beverages) yang Terdaftar di Bursa Efek Indonesia (BEI) Periode 20132016. Journal of Management, 4(4). https://doi.org/2502-7689

Awwaliyah, N. M. A. Al, Djaelani, A. K., \& Rahman, F. (2019). Pengaruh Pendapatan Premi, Hasil Underwriting, Beban Operasional Dan Hasil Investasi Terhadap Laba Pada Perusahaan Asuransi Umum Yang Terdaftar Di BEI Periode Tahun 2017-2019 Oleh: E - Jurnal Riset Manajemen, 123-134.

Babayeva, N. M. (2021). On the Issue of Effective Modeling of The Investment Portfolio of Insurance Companies. Journal of Contemporary Issues in Business and Goverment, 27(3), 2124-2128.

https://doi.org/10.47750/cibg.2021. 27.03.209

Bacinello, A. R., Chen, A., Sehner, T., \& Millossovich, P. (2020). On the Market-Consistent Valuation of Participating Life Insurance Heterogeneous Contracts under Longevity Risk. Risks, 9(20), 2-18. https://doi.org/10.3390/risks 90100 20

Berry, T. R., \& Jianren, S. (2021). Local religious beliefs and insurance companies' risk - taking behaviour. In The Geneva Papers on Risk and Insurance - Issues and Practice (Issue 0123456789). Palgrave Macmillan UK. https://doi.org/10.1057/s41288021-00211-z

Damayanti, E. N., \& Kuswanto, H. (2019). Analisis Risiko Pada Return Saham Perusahaan Asuransi Menggunakan Metode VaR dengan Pendekatan ARMA-GARCH. Jumal Matematika, Statistika \& Komputasi, 16(1), 40-50. https://doi.org/10.20956/jmsk.v

Dharma, B. (2019). Comparative Analysis of Financial Statements for Insurance 
Companies with Reference to F Values. Journal of Engineering Sciences, 10(12), 1225-1234.

Dhiab, L. B. E. N. (2021). Determinants of Insurance Firms' Profitability: An Empirical Study of Saudi Insurance Market. Journal of Asian Finance, Economics and Business, 8(6), 235-243. https://doi.org/10.13106/jafeb.2021 .vol8.no6.0235

Egam, G. E. Y., Ilat, V., \& Pangerapan, S. (2017). Pengaruh Return on Asset (ROA), Return on Equity (ROE), Net Profit Margin (NPM), dan Earning Per Share (EPS) Terhadap Harga Saham Perusahaan Yang Tergabung Dalam Indeks LQ45 Di Bursa Efek Indonesia Periode Tahun 2013-2015. Jurnal EMBA, 5(1), 105-114. https://doi.org/10.1007/978-1-34915400-5_6

Geriadi, M. A. D., \& Wiksuana, I. G. B. (2017). Pengaruh Inflasi Terhadap Return Saham Pada Perusahaan Properti Dan Real Estate Yang Terdaftar Di Bursa Efek Indonesia (Risiko Sistematis Dan Profitabilitas Sebagai Variabel Mediasi). E-Jurnal Ekonomi Dan Bisnis Universitas Udayana, $9, \quad 3435$. https://doi.org/10.24843/eeb.2017. v06.109.p10

Harnida, M. (2017). Pengaruh Corporate Governance dan Faktor Fundamental Terhadap Return Saham Pada Perusahaan Manufaktur Yang Terdaftar Di Bursa Efek Indonesia. Jurnal KRISNA: Kumpulan Riset Akuntansi, 9(1), 36-49. https://doi.org/10.31602/alkalam.v4i2.968

Hayati, M. (2016). Investasi menurut perspektif ekonomi islam. IKONOMIKA; Jurnal Ekonomi Dan Bisnis Islam (Journal of IslamicEconomics and Business), 1(I), 66-78.

Hutapea, A. W., Saerang, I. S., \& Tulung, J.
E. (2017). Pengaruh Return On Asset, Net Profit Margin, Debt to Equity Ratio dan Total Aset Turnover Terhadap Harga Saham Industri Otomotif Dan Komponen Yang Terdaftar di Bursa Efek Indonesia. Jurnal EMBA, 5(2), 541-552.

Leviany, T., \& Sukiati, W. (2014). Pengaruh Risk Based Capital Terhadap Profitabilitas Pada Perusahaan Asuransi Jiwa. Jurnal Aset (Akuntansi Riset), 7(1), 1-12.

Markonah, M. (2021). Analysis Relates to The Role of Premium Income, Claim Expenses, Investment Result and Risk Based Capital (RBC) Against The General Insurance Companies' Profits Income (Case Study On General Insurance Which Registered In The Indonesia Stock Exchange). Dinasti International Journal of Economics, Finance and Accounting, 2(1), 132-146.

Marsanto, S. A. S., Mulyantini, S., \& Fadila, A. (2021). Pengaruh tingkat kesehatan terhadap profitabilitas perusahaan asuransi yang terdaftar di bursa efek indonesia. KORELASI; Konferensi Riset Nasional Ekonomi, Manajemen, Dan Akuntansi, 2(1), 1759-1773.

Möhlmann, A. (2021). Interest rate risk of life insurers: Evidence from Accounting Data. Financial Management, 50, 587-612. https://doi.org/10.1111/ fima.12305

Mubarok, F. K. (2018). Peran sosialisasi dan edukasi dalam menumbuhkan minat investasi di pasar modal syariah. Inovasi, 14(2), 113. https://doi.org/10.29264/jinv.v14i2. 4119

Mubarok, F. K. (2019). Analisis Implementasi Corporate Social Responsibility Pada Perusahaan Berlabel Syariah Di Bursa Efek Indonesia. Media Trend, 14(2), 154 165.

https://doi.org/10.21107/mediatren 
d.v14i2.4539

Mubarok, F. K., Darmawan, A. R., \& Luailiyah, Z. (2017). Optimalisasi Portofolio Nilai Saham: Studi Komparasi Kinerja Saham Syariah dan Nonsyariah. Economica: Jurnal Ekonomi Islam, 8(2), 309. https://doi.org/10.21580/economic a.2017.8.2.2368

Nababan, M., Mangantar, M., \& Maramis, J. B. (2019). Dampak Inflasi, Suku Bunga, Struktur Modal Terhadap Risiko Bisnis, Return Saham Asuransi DI BEI. Jurnal EMBA, 7(4), 4639_ 4650.

Nur, F., Samalam, A., Mangantar, M., Saerang, I. S., Ekonomi, F., Bisnis, D., Manajemen, J., Sam, U., \& Manado, R. (2018). Pengaruh Return on Asset, Return on Equity Dan Debt To Equity Ratio Terhadap Return Saham Pada Perusahaan Asuransi Di Bei Periode 2012-2016. Jurnal EMBA: Jurnal Riset Ekonomi, Manajemen, Bisnis Dan Akuntansi, 6(4), 3863-3872. https://doi.org/10.35794/emba.v6i4 .21912

Oudat, M. S., \& Ali, B. (2021). The Underlying Effect of Risk Management On Banks' Financial Performance: An Analytical Study On Commercial and Investment Banking in Bahrain The Underlying Effect of Risk Management On Banks' Financial Performance: An Analytical Study On Commercial a. Elementary Education Online, 20(5), 404-414.

https://doi.org/10.17051/ilkonline.2 021.05 .42

Oussama, A., \& Lamine, A. (2021). The effect of compensation on the insurance surplus and the profitability of Takaful insurance companies A case study of the Islamic insurance company in Jordan, 2010-2019. Economic Sciences, Management and Commercial Sciences Review, 14(01), 762-
774.

Permana, S. J. (2017). Analisis FaktorFaktor Yang Memengaruhi Abnormal Return Saham Pada Perusahaan Perbankan Dan Asuransi Yang Terdaftar Di Bursa Efek Indonesia. Bisma, 11(1), 12-27. https://doi.org/10.19184/bisma.v11 i1.6205

Reyna, A. M., Fuentes, H. J., \& Núñez, J. A. (2021). Response of Mexican life and non - life insurers to the low interest rate environment. The Geneva Papers on Risk and Insurance - Issues and Practice, 0123456789. https://doi.org/10.1057/s41288021-00208-8

Rivero, R. A. B., Ramírez, M. A. N., \& Río, S. V. Del. (2021). Interaction of Economic Policy. Lessons on Social Welfare and Risk Premium. Montenegrin Journal of Economics, 17(1), 7-29.

Rustamunadi, \& Amaliah, S. (2020). Pengaruh Hasil Investasi Terhadap Laba Bersih Pada Perusahaan Asuransi Jiwa Syariah di Indonesia (Studi pada Perusahaan Asuransi Jiwa Syariah yang Terdaftar di Otoritas Jasa Keuangan Periode 2014-2018_. Jurnal Syar'Insurance, 6(2), 105-124.

Saida, R. (2021). The effectiveness of Kida model for predicting financial failure of insurance companies in Algeria - A Field Study-. Journal of Economic Growth and Entrepreneurship JEGE, 4(5), 1927.

Sastrodiharjo, I., \& SUtama, I. P. (2015). Faktor-Faktor Yang Mempengaruhi Pertumbuhan Aset Perusahaan Asuransi Jiwa. AKUNTABILITAS, $\operatorname{VIII}(1), 18-38$.

Sena, C. M. K., \& Suherman. (2021). Tanggung Jawab Hukum Perjanjian Asuransi Jiwa Unit Link di PT. Prudential Life Assurance Jakarta Christine. Wajah Hukum, 5(1), 61-69. 


\section{At-Taqaddum}

Vol. 13 No. 1 (2021) Pg. 73-84

https://doi.org/10.33087/wjh.v5i1.3 42

Suyatna, N. (2021). Pengaruh PSAK 108 , Produk Unit Linked terhadap Asumsi Going Concern Perusahaan Asuransi Syariah di Indonesia. Jurnal Ilmiah Ekonomi Islam, 7(02), 908-916.

Thuku, C. W. (2021). Risk Transfer Strategy And The Performance Of Insurance Companies In Nyeri County, Kenya. International Journal of Innovative Research and Advanced Studies (IJIRAS), 8(2), 28-33.

Tian, Y., Guo, J., \& Sun, Z. (2021). Optimal Mean-Variance Reinsurance in A Financial Market with Stochastic Rate of Return. Journal of industrial and management optimization, 17(4), 1887 1912.

https://doi.org/10.3934/jimo.20200 51

Upreti, V., Adams, M., \& Jia, Y. (2021). Risk management and the cost of equity: evidence from the United Kingdom' s non-life insurance market. The European Journal of Finance, $1-20$.

https://doi.org/10.1080/1351847X. 2021.1936588

Wang, K., \& Zhu, L. (2021). Solvency Evaluation Model of Insurance Company Based on Stochastic Dirrential Equation. Complexity, 1-12.
Worotikan, E. R. C., Koleangan, R. A. M., \& Sepang, J. L. (2021). Pengaruh Current Ratio (CR), Debt To Equity Ratio (DER), Return on Assets (ROA) Dan Return on Equity (ROE) Terhadap Return Saham Pada Perusahaan Food And Beverages Yang Terdaftar Di Bursa Efek Indonesia Pada Tahun 2014-2018 The Effect of Current R. Jurnal EMBA, 9(3), 1296-1305.

Zhang, J. (2021). Dynamic Index Optimal Investment Strategy Based on Stochastic Differential Equations in Financial Market Options. Wireless Communications and Mobile Computing, 1-9.

Zharikova, O., \& Cherkesenko, K. (2021). Integration of banks and insurance companies activities in Ukraine. Journal of Scientific Papers "Social Development and Security," 11(2), 0-3. https://doi.org/10.33445/sds.2021.1 1.2 .5

Zulkarnaen, Z. (2018). Pengaruh Debt To Assets Ratio Terhadap Return on Asset Pada Perusahaan Asuransi Yang Terdaftar Di BEI Tahun 2010 2015. Jurnal Warta, 56(April), 82-82. https://doi.org/10.1007/0-38726336-5_580 